\title{
Studying the Efficiency of Irrigation with Micro-Irrigation
}

\author{
Rae ZH Aliyev* \\ Institute of Erosion and Irrigation NAS of Azerbaijan, Baku
}

Submission: January 04, 2018; Published: January 17, 2018

*Corresponding author: Rae ZH Aliyev, Institute of Erosion and Irrigation of ANAS of Azerbaijan, Baku, Email: Volqa_5@mail.ru

\begin{abstract}
The results of the study revealed that the mismatch intensity rain rate of water absorption into the soil formation of a surface relief and soil erosion, uneven and shallow soaking imperfection open irrigation system at a superficial irrigation, the need for different irrigation methods in the growing and not growing periods, low coefficient land utilization, high cost of irrigation and other features are, to a certain extent in conflict with the requirements of watering cultivated with techniques for / of crops in an area at the deep groundwater.
\end{abstract}

Keywords : Irrigation interval; Irrigation; Water capacity; Groundwater; Loam; A count unit; Slope; Soil fertility

\section{Introduction}

The increase in the production of agricultural crops is one of the priorities of agrarian production in Azerbaijan, both for meeting domestic needs and for exporting them. In solving this problem, a significant role belongs to the regions, the natural and climatic and economic and economic conditions of which are favorable for the successful development of irrigated agriculture. And taking into account the long traditions and high level of professional training of agricultural specialists, the experience of the population and the transfer of this direction to the private sector, we can safely assert not only the development of mountain-irrigated agriculture in Azerbaijan in the coming years, but its revival based on the introduction of high-performance modern technologies Irrigation, as pulsed sprinkling, micro-irrigation, pulsed sprinkling of self-oscillating action, combined irrigation, impulse rain Self-oscillating action with automated control and a number of others. Taking into account that the territory of Azerbaijan, which is the most favorable for cultivation of various types of crops by natural conditions, is located in zones of unstable and insufficient moisture, the intensification of fruit growing is possible only with the use of low-intensity irrigation systems. The necessity of using this kind of irrigation is also due to the increased demand of agricultural crops for moisture supply.

\section{Course of research and discussion of results}

At the research facilities on the territory of the Republic, irrigation with micro-irrigation was carried out on medium and large slopes with a deep level of groundwater in the period
2005-2011. At the same time, the cultivation of fruit trees with an irrigation device of the IDAD type and a micro-diver of various modifications was studied in the experimental site of the OEB of the Institute of Erosion and Irrigation of ANAS in the village of Malakh of the Shemakha district with an area of 4.82 hectares, in the period 2006-2010, in the Guba RWC in the Shahdag foothills on an area of 2.8 hectares, in the period 2004-2006, the work was also carried out in the Ganja district of the PAC in the village of Ganja, Bagmanly with an area of 4.45 hectares, in the period 2007-2011 on irrigated light chestnut soils with a maximum moisture capacity of $3000-3100 \mathrm{~m} 3 /$ ha and on deep-seated serozems.

Groundwater in the Alazansky valley of the Zakatala district in the period 2004-2006. 49 irrigations (500-650 m3/ha) with an irrigation rate of $1890 \mathrm{~m} 3$ / ha were carried out. Only the upper layer of the soil $(28-30 \mathrm{~cm})$ was moistened. In the middle of July, the moisture content of the soil in the $30 \mathrm{~cm}$ layer decreased to $40 \%$ (from PPW), and in early September to $40-60 \%$ (in the meter layer), which led to drying and a decrease in maize yield for silage and winter wheat. At the control plot (five irrigation on furrows with an irrigation rate of about $16,000 \mathrm{~m} 3 / \mathrm{ha}$ ), the humidity was $80-100 \%$ of PPV. As a result of the research it was recommended to optimize the irrigation norm, the number of irrigation and the reduction of inter-irrigation periods; It was pointed out that it was expedient to use sprinkling with the use of the design developed by the author for the various modifications of micro araners tested at the experimental site, where watering along the furrows proved to be difficult, and in general impossible at all. 
At the Institute of Erosion and Irrigation of ANAS with the participation of the author, experiments on irrigation with the IDAD apparatus and other modifications of the micro-irrigation irrigation technique of various types of agricultural crops on newly developed rainfed lands have been continued. On the example of the objects of research on which the experiments on the problems of the development of mountain-irrigated agriculture in the zones of Guba-Khachmas, Ganja-Gazakh, Garabagh, Upper Shirvan, Sheki-Zagatala and other regions of the republic were laid. It should be noted that in the zones of the experiment the soils are overlying, felling, loam (sierozem), and so on. Land with different soil characteristics, and in all these zones of the experiment the groundwater table is deep.

With all this, it was planned to increase the density of plants and not to conduct inter-row treatments. From the experimental sites on the territory of the research objects, from which a «registration site» with more amicable shoots was isolated, divided into plots located at the site of the Shemakha OEB Institute of Erosion and Irrigation of ANAS in the village of Malham and Guba RAN in the foothills of Shahdag in the Guba area with a total area of 4, 82 hectares (Table 1). During the vegetation period, 94 irrigation operations were carried out with an estimated irrigation rate of $4590 \mathrm{~m} 3 / \mathrm{ha}$, which did not ensure normal soaking of the soil. The height of the fruit tree plants (about $5.0 \mathrm{~m}$ ) and the area along the humidification contour (8-10 m2), which was less than in furrow irrigation. The root system spread in the depth of the layer 2.0-2.5 m, and with furrow irrigation in the depth of the layer more than $3.0 \mathrm{~m}$.

Table 1:

\begin{tabular}{|c|c|c|}
\hline Variants Width & Between rows, $\mathbf{m}$ & $\begin{array}{c}\text { Density of standing } \\
\text { Plants, thousand } \\
\text { pieces / ha }\end{array}$ \\
\hline I & $4,5-5,0$ & 198 \\
\hline II & $2,8-3,0$ & 280 \\
\hline III & $2,2-2,5$ & 383 \\
\hline
\end{tabular}

Moistening of such a small area was uneven, and yields in more moistened areas in apple orchards in the Guba region amounted to 210.9 centners per hectare and 189 centners per hectare at the Ganja RCAN, and on drained respectively 147.3 and 113.9 centner/ha. The absence of cultivation of crops under the narrowed between rows led to a strong compaction of the soil and a decrease in water permeability, which increased the surface runoff during irrigation. The increase in the density of standing did not have a noticeable effect on the suppression of weeds. The development and growth of fruit (apple, pear, peach, persimmon, etc.) passed at relative soil moisture of $20-40 \%$, soaking did not exceed $35 \mathrm{~cm}$.

Originally in 2006-2008. In order to select the object of the study, we chose an experimental site in the OEB of the Erosion and Irrigation Institute of ANAS in the village of. Malham of the Shemakha district, on the OEP of the Guba RUCN in the Guba district. On the Shahdag foothills with a common With an area of 2.8 hectares and on the EIA of Gyandzhinskiy RUCN in the village. B / Bagmanly with an area of 4.45 hectares. The soils of these massifs are medium-thick $(30-40 \mathrm{~cm})$, with slopes greater than -0.02-0.025. Carrying out watering on the furrows is difficult, because of the complex terrain. Therefore, it was planned to sprinkle with small norms, using micro-razors of various modifications.

Water supply for irrigation in these areas (with a total area of more than 8 hectares) was carried out from hydrants installed through 85, 120, $200 \mathrm{~m}$ on the corresponding transport pipelines, into open sprinklers (at a rate of 60, 80, $100120 \mathrm{l} /$ $\mathrm{sec}$ ), cut Perpendicular to it. It was found that at irrigation rates of 300-420 m3 / ha the soil is soaked to insignificant depth (2030 , sometimes up to $40 \mathrm{~cm}$ ). The low absorption rate of the upper soil layer and large slopes provided a significant surface discharge $(30 \%)$, increasing from irrigation to irrigation. The addition of moisture in the soil was only 100-300 m3/ha. Small irrigation rates require private watering (after 5-6 days). The supply of large irrigation norms (600-700 $\mathrm{m} 3 /$ ha and more) is difficult due to a mismatch in the intensity of the rain $(2-3 \mathrm{~mm} /$ $\mathrm{min}$ ) and the rate of water absorption into the soil.

Large drops of rain destroy the structure of the soil, and the upper 2-3 cm are swollen; The absorption rate decreases, resulting in a surface discharge. Then, an experimental site for micro-irrigation for watering vineyards, soybeans, sugar beet, corn for silage, fruit trees was organized, in the territory of Ganja RACC of the village. B / Bagmanly with an area of 4.1 hectares and AIA of the Agricultural Research Institute of the Terter region with an area of 1.5 hectares. The soils of the site (with a total area of more than 30 hectares) are average loams, gradients of 0.005 (Figure 1). And so in 2009-2011 irrigation norm was performed with irrigation norm of $3700-4200 \mathrm{~m} 3$ / ha (irrigation norms from 350 to $550 \mathrm{~m} 3$ / ha).

Moisture in the $60 \mathrm{~cm}$ layer did not drop below $60 \%$ of the PPV, and after irrigation it was $80-90 \%$ of the PPV. Soaking of the soil was no more than $30-50 \mathrm{~cm}$ (most of the water in the 20 cm layer).

The yield for soybean production was 14-17 c / ha. In 2010, late-spring water recharge was performed on the upper part of the site (with an area of 0.6 hectares) (the groundwater level here was deep, and the rest of the site varied from 2 to $5.5 \mathrm{~m}$ ). Reserves of moisture in the soil were insufficient to produce shoots, so in mid-May, the reseeding was carried out after the presowing irrigation with the norm of 250-300 m3 / ha. Where, irrigation was conducted in this period with an irrigation rate of 3800-4200 m3/ha. Further all this work was expanded in the Samukhsky area of corn on the trees and mulberry trees, in the Shamakhi district in vineyards, in the Guba district of fruit gardens, Khachmas district of vegetable crops (cabbage, eggplant). Studies on sprinkling in this facility have shown that 


\section{Global Journal of Otolaryngology}

the rainfall in the IDAUD ( $3 \mathrm{~mm} / \mathrm{min}$ ) is greater than the rate of water absorption into the soil of the research object. Therefore, when feeding $500 \mathrm{~m} 3$ / ha, puddles and surface discharges were formed at the site. Figures 1 \& 2 Scheme of the irrigation sprinkling station on the experimental part of the Tertersky
RWCN in the Garabagh land in the period 2006-2010 with the use of the Idad and MDR sprinklers.

them occupy $6-8 \%$ of the area; For example, in this case, water losses in irrigation systems built in the Guba RRCN were 30-35\%

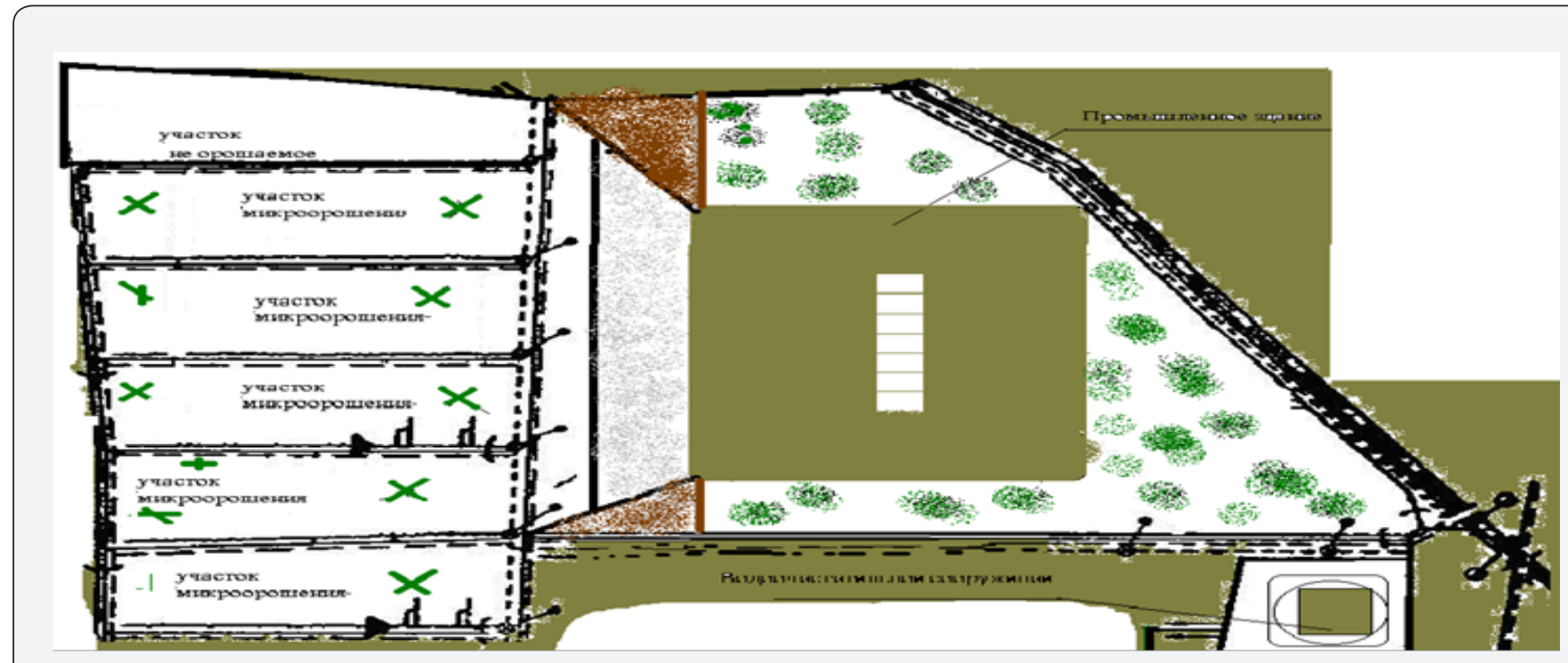

Figure 1: Scheme of the irrigation sprinkling station on the experimental part of the Tertersky RWCN in the Garabagh land in the period 2006-2010 with the use of the Idad and MDR sprinklers.

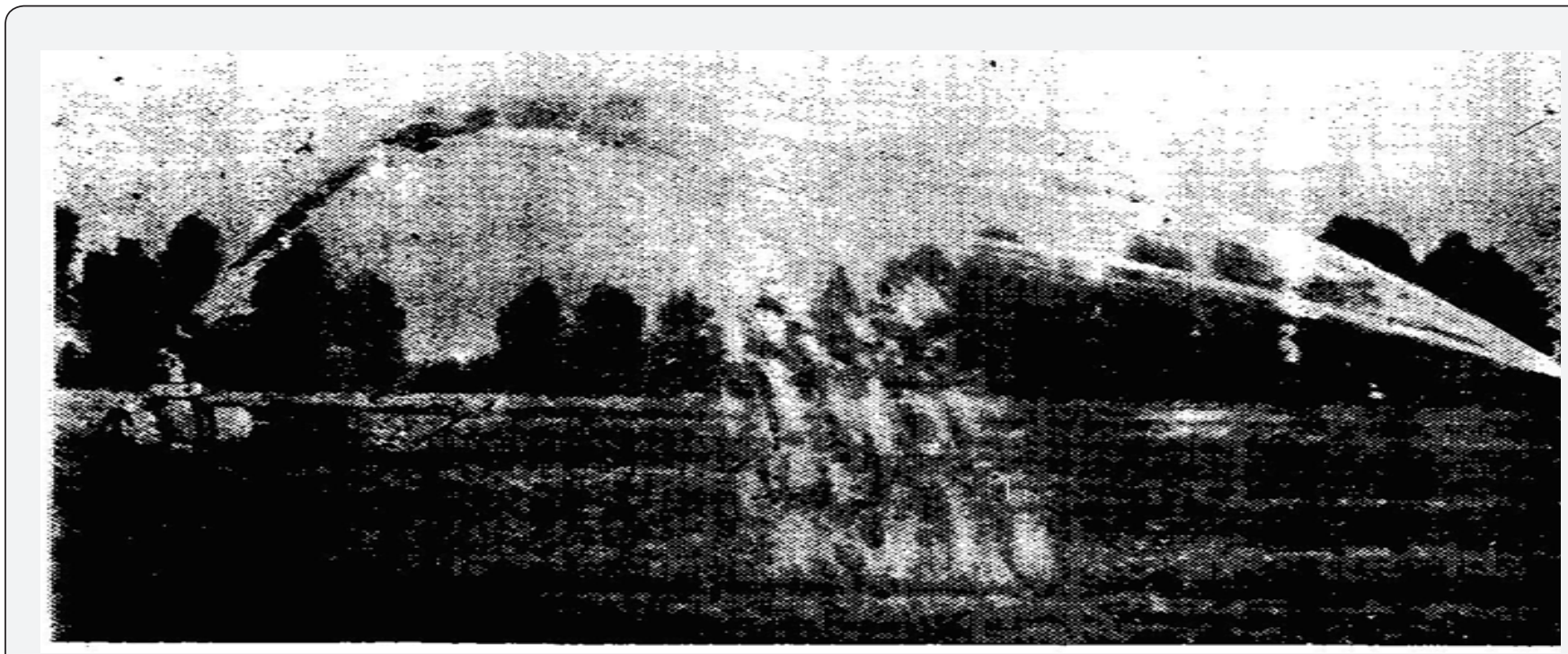

Figure 2: Demonstrations of the micro irrigation regime with the use of IDAH in conditions of irrigation of sugar beet, maize for power and soya in the Terter AIS of the Institute of "Agriculture".

The discharge was $20-30 \%$, which led to uneven moistening At the beginning of vegetation due to timely treatments, the surface discharge decreased (up to $8-10 \%$ ). When the treatment of crops ceased, the discharge again reached $16-17 \%$. Demonstrations of the micro irrigation regime with the use of IDAH in conditions of irrigation of sugar beet, maize for power and soya in the Terter AIS of the Institute of «Agriculture». Soaking of the soil during watering did not exceed $30-60 \mathrm{~cm}$.
Greater wetting and better uniform moisture distribution under these conditions is achieved with irrigation rates of more than $300-400 \mathrm{~m} 3$ / ha. At such rates about $60-70 \%$ of water remains in the upper $(20 \mathrm{~cm})$ layer, and the plants are not completely supplied with moisture.

A big drawback with the irrigation of the Idad apparatus in the presence of an irrigation network, impassable for machining mechanisms. It was found out that sprinklers and roads along 
per $1 \mathrm{~km}$, and in Terter AOS 20-25\% (Table 2). The conditions for micro adjustment of IDAID vehicles on the territory of the Guba RUCN during irrigation of orchards, on the territory of the AIA of the Agricultural Research Institute in Terter district, Sarydzhaly sugar beet and soybeans, in the Ganja RUCN in the village. B/Bagmanly orchards and vineyards. The distribution of water in micro-irrigation according to calculations (according to B.H.Aliyev's method) was as follows (Table 3). At the same time, the greatest losses occurred in the discharge and evaporation.

Small irrigation rates (before the formation of runoff) require a large number of irrigation. Thus, in the Shemakha region, in the experiments carried out by the Shamakhi EIA of

Table 2: The conditions for micro adjustment of IDAID vehicles on the territory of the Guba RUCN.

\begin{tabular}{|c|c|c|c|}
\hline Indicators of the & “Guba RATSN" & “Tertersky RATSN" & “Ganja RATS" \\
\hline Type of soil & Loess-like loams & Pebble-gravel (low-power) & Loess-like loam \\
\hline Limit-field moisture, m3 / ha (PPV) & 2970 & 1100 & 2500 \\
\hline $\begin{array}{l}\text { Water permeability in the 1st hour, } \\
\mathrm{m} / \mathrm{h}\end{array}$ & $0,03-0,05$ & 0,06 & 0,04 \\
\hline Slopes & $0,001-0,0001$ & $0,02-0,03$ & $0,004-0,007$ \\
\hline $\begin{array}{ccc}\text { Depth } & \begin{array}{c}\text { of occurrence } \\
\text { groundwater, } \mathrm{m}\end{array} & \text { of } \\
\end{array}$ & $1-4$ & More than & $2,5-7-10$ \\
\hline $\begin{array}{c}\text { Surface discharge from irrigated } \\
\text { area, } \%\end{array}$ & no & Up to 30 & As much as possible \\
\hline $\begin{array}{l}\text { Wet-charge irrigation } \\
\text { watering, m3 / ha } \\
\text { Productivity, q / ha }\end{array}$ & $\begin{array}{c}\text { Carried out in winter } \\
2500-3000 \\
30-40\end{array}$ & $\begin{array}{l}\text { Conduct inappropriate } \\
\qquad 5-10\end{array}$ & $\begin{array}{c}10-20 \\
\text { Held in the late-sen.perd } \\
1500 \\
15-20\end{array}$ \\
\hline
\end{tabular}

Table 3: Water balance during sprinkling in the experimental areas of Terter Shamakhi and Ganja RWC

\begin{tabular}{|c|c|c|c|c|c|c|}
\hline \multirow[t]{2}{*}{ Статъи баланса } & \multicolumn{2}{|c|}{$\begin{array}{l}\text { Гянц्रхтаском } \\
\text { РАЦН }\end{array}$} & \multicolumn{2}{|c|}{$\begin{array}{l}\text { Tepтерского } \\
\text { РАЦН }\end{array}$} & \multicolumn{2}{|c|}{$\begin{array}{l}\text { Шамmxтанкого } \\
\text { РАЦН }\end{array}$} \\
\hline & $\mathbf{m}^{3} / \mathbf{r a}$ & $\%$ & $\mathbf{m}^{3} / \mathbf{r a}$ & $\%$ & $\mathbf{m}^{3} / \mathbf{r a}$ & $\%$ \\
\hline Приход $\ldots \ldots \ldots \ldots \ldots$ & 644 & 100 & 693,7 & 100 & 657,2 & 100 \\
\hline $\begin{array}{l}\text { всего..................... } \\
\text { В том числе: }\end{array}$ & 644 & 100 & 693,7 & 100 & 657,2 & 100 \\
\hline фильтрация в почву...... & 16,2 & 2,6 & 55,7 & 8,0 & 49,7 & 22,9 \\
\hline точньй объем............... & 7,1 & 1,1 & 10,0 & 1,4 & 14,7 & 1.25 \\
\hline Испарение при падении & & & & & & \\
\hline капель дож дя на землю.... & 81,2 & 12,6 & 88 & 12,7 & 86,3 & 14.1 \\
\hline Сброс с поля .............. & 86,5 & 13,4 & 162 & 23,4 & 183.4 & 19.7 \\
\hline осталось на поле.......... & 453 & 70,3 & 378 & 54,5 & 484,8 & 42,07 \\
\hline
\end{tabular}

Water balance during sprinkling in the experimental areas of Terter Shamakhi and Ganja RWC Irrigated standards for various soils and slopes, under which the runoff of water begins, where the results of the study are shown in (Table 4). According to B.H. Aliyev, the surface discharge in the Guba RNCN zone during watering of apple gardens on the territory of the experimental plot is 7-8\% until August, and in August -20\%, which testifies to the results of the research in the period 2006-2011. It should be noted that even according to the results of the studies carried out in the Terter region on small slopes and fertile soils, where fields are leveled annually, even after feeding 350-400 m3/ha, puddles appear on the surface of the field. When testing the IDAA with deflector nozzles both in the Guba-Khachmaz RADSN and in the Terter AOS (rain intensity $0.7-1.2 \mathrm{~mm} / \mathrm{min}$ ), positionally, the formation of puddles and runoff on medium and heavy soils at irrigational norms of $250-300 \mathrm{~m} 3 / \mathrm{ha}$.

Table 4: Irrigated norms (m3/ha) before the appearance of runoff based on the results of the conducted study in the regions of Guba-Khachmaz and Ganja-Gazakh zone.

\begin{tabular}{|c|c|c|c|c|}
\hline \multirow{2}{*}{ Soil } & \multicolumn{3}{|c|}{ Slopes } \\
\cline { 2 - 5 } & \multicolumn{2}{|c|}{$\mathbf{0 , 0 0 0 2 - 0 , 0 0 0 5}$} & First watering & \multicolumn{2}{c|}{ Last watering } \\
\cline { 2 - 5 } & First watering & Last watering & 400 & 170 \\
\hline Sandy loam & 450 & 230 & 290 & 100 \\
\hline$\ldots \ldots \ldots \ldots \ldots \ldots \ldots \ldots \ldots$ & 340 & 150 & 170 & 80 \\
\hline Light loam & 290 & 90 & \\
\hline
\end{tabular}


the Institute of Erosion and Irrigation of ANAS (4.8 ha) on heavy soils with a deep bedding of groundwater at the same irrigation rate (7000-7500 m3 / ha), the number of irrigations with microirrigation (42-53) Was significantly larger than in the case of furrows along furrows [1-17]. To combat cortex and compaction, it was necessary to sharply increase the number of inter row treatments (up to 10), which did not completely destroy the crust near the stem. Shallow and uneven soaking of the soil and untimely processing of crops led to a marked reduction in yield during sprinkling.

Production experiments on micro-irrigation were carried out in the Zakatala district. The tests of sprinkler technology such as IDAD, MDP, MDR and developed by us have established that with a deep level of groundwater and a complex relief, the use of IDA, on watering tobacco and corn, apple, etc. is more promising than other dominant traditional (surface) methods of irrigation. The results of the test revealed that to reduce the intensity of rain on the sprinkling heads of the apparatus, special nozzles-vichrators were mounted for sprinkling up to $40 \mathrm{~m}$ in radius and more than the action and added additional devices for regulating the rain layer, which helped to suppress pressure in the pump discharge port. All this allowed to reduce the intensity of rain and give irrigation rates of 600-700 m3 / ha (with a daily mode of operation) without significant surface discharge and soil erosion. Such measures can reduce run-off, but this reduces labor productivity in watering. However, it is also difficult to equip sprinklers with a higher water delivery rate in the range of 800-1000 m3 / ha, where significant planning work is required.

The proposed nozzles installed on the ISAD sprinkler have a relatively low rain intensity, which is explained by the desire to create a microclimate over plants with low water consumption, with limited geometry of the irrigated area. Experience proves that with increasing capture width, it would be possible to reduce the intensity of rain while retaining labor productivity. The experimental work carried out by us at the above-mentioned research facilities in Terter, Zagatala and Ganja on irrigating soybeans, sugar beet, maize and tobacco makes it possible to give an approximate average rain intensity ( $\mathrm{mm} / \mathrm{min}$ ) at irrigation rates of 300-500 m3 / ha, depending on the soils: Sandy -0,3 0,4, light loamy -0,2 0,3, medium and heavy loam -0,1 0,2. Apparently, a wide production check of this irrigation technology, taking into account the recommended rain intensity, will allow us to clarify the technical and economic indicators and the conditions for the application of micro-irrigation.

\section{Conclusion}

The analysis has shown that irrigation with micro-irrigation can also find its spread in conditions of close lying of nonsaline groundwater. At a high level of groundwater, high yields of agricultural crops can be achieved, however, technical and economic indicators at the given level of development of sprinkling equipment in the presence of socio-economic conditions of life of farming and other farms of the republic are less favorable than surface furrow irrigation. Further improvement of sprinkler systems with higher technical and economic indicators, possibly, will allow to expand irrigation area of micro-irrigation in conditions of mountain-irrigated agriculture in Azerbaijan. For this purpose, in the future, micro irrigation systems of the type IDAD and others proposed for serial production were not tested in the republic for any more (except for research objects) for sprinkling.

\section{References}

1. Aliyev ZH, Aliyyev BH (2002)Suvarm sistemarilinina optimallashydyrilmasy. The patent № P 20020232, Baky i silt.

2. Aliyev ZH, Aliyev BH, Aliyev IN (2002) Avtoryagsli impulslu damylam aparata. № P Patent 20020179, Baky.

3. Aliyev ZH, Aliyev BH (2002) Impulslo Su Burakhyo. Patent No. P 20020196, Baky, Ill.

4. Aliyev ZH, Aliyev BH, Nuriev Sh (1999)Asta yayysyaydyyry systems. Patent No. R.990100 Baka-s il.

5. Aliyev ZH, Aliyev BH (1998) Suvarmanin avtomatlashyrylmysh and idaryatmya sis-that/No. I Patent Baky 2001 0098-s il.

6. Aliyev ZH, Aliyev BH (2005) Addymla yayyshyadyran apparatus. Patent I 0101 No.

7. Aliyev ZH, Aliyev BH (2016) Avtomatlashdyrylmysh distances and hurricanes. Patent No P990050.

8. Aliyev ZH (2000) Suvarm sistemararinin optimallashdyyrilmasy" Patent No I 99001624.

9. Aliyev ZH, Aliyev BH (2006) Impulsely Suburahyy" Patent No I 20000152.

10. Aliyev ZH, Aliyev BH (2015) Suvarmanin optimalallardym system." Patent No I 20040178.

11. Aliyev ZH (2004) Azarybayanin give yakinchilya Šrayaitindyaki torpaga vja suestiyatatlaryndan syamyaryal ilyfrya va nalaryna of the Oled of the Olunmas. Zh AAE № 1-3 syll 106-111.

12. Aliyev ZH (2008) Azarybayanin give yakinchilya sharyaitindya suvarmanin automatics of the Iliad of olunmasynyna yasaslar. Monograph Publishing house "Zia-Nurlan" LLC 202 with Baku.

13. Aliev ZH (2003) Development and implementation of a pulse-sprinkling device for auto oscillatory action in the mountainous and foothill region of Azerbaijan: Abstract of the dissertation. Candidate of Agricultural Sciences Baku.

14. Aliev ZH, Aliev BH (1998) Irrigation techniques for farmers and peasant farms in Azerbaijan Monograph, "Azerneshr" Publishing House Baku, 113.

15. Aliyev ZH, Aliev BH (2001) Zoning of the territory of the Republic of Azerbaijan for the selection of progressive irrigation technology. Monograph Ziyaya Publishing House Baku 297

16. Aliyev ZH, Aliev BH (2003) Irrigated agriculture in the mountain and foothill regions of Azerbaijan. Monograph Publishing house "Ziya-Nurlan EPP LLC" Baku $330 \mathrm{p}$.

17. Aliyev ZH, Aliev BH (2005) Automated management of low-intensity irrigation in the conditions of Azerbaijan. Monograph Publishing house "Zia-Nurlan EPP Ltd." Baku 400 p. 
(C) This work is licensed under Creative BY DOI: $10.19080 /$ GJ0.2018.13.555853
Your next submission with Juniper Publishers will reach you the below assets

- Quality Editorial service

- Swift Peer Review

- Reprints availability

- E-prints Service

- Manuscript Podcast for convenient understanding

- Global attainment for your research

- Manuscript accessibility in different formats

( Pdf, E-pub, Full Text, Audio)

- Unceasing customer service

Track the below URL for one-step submission https://juniperpublishers.com/online-submission.php 